\title{
Right Oblique Transthoracic Electrocardiogram
}

\author{
A. REDFORS, S-E. SVENSSON, AND H. WETTERQVIST \\ From the Laboratory of Clinical Physiology, the University.Hospital, Lund, Sweden
}

In clinical electrocardiography many attempts have been made to achieve a higher degree of accuracy in the interpretation. One controversial subject is whether unipolar chest leads are more useful than bipolar ones (Einthoven and de Lint, 1900; Lewis, 1910; Drury and Iliescu, 1921; Koenigsfeld and Stroebe, 1923; Ackermann, 1924; Wolferth and Wood, 1932; Weinstein, 1934; Whitten, 1937; Nylin and Sällström, 1938; Nehb, 1938; Bengtsson, 1947; Grewin, 1948; Carlsten, 1954; and others). Evans has been studying this problem for many years (Evans and Hunter, 1943; Evans, 1965). Latterly he tested a transthoracic lead with the indifferent electrode placed in the 4th intercostal space at the right sternal border (station 1) and the exploring electrode placed in the left posterior axillary line (station 7).

According to Evans this "right oblique lead" gives more information than conventional leads in patients with lateral or postero-lateral infarction. We, therefore, began using this lead together with routine leads at rest and in connexion with exercise tests, and hoped to achieve an improvement in the reliability of diagnosing coronary insufficiency. We also recorded the right oblique lead in normal subjects.

\section{SubJeCtS AND Methods}

An ordinary direct-writing electrocardiograph (Mingograph, Elema) was used. The determination of the physical working capacity was made according to the routine method used in the laboratory and described by Sjöstrand (1947, 1960) and by Wahlund (1948). The work was performed on an electrically braked bicycle ergometer designed by Holmgren and Mattsson (1954). The leads I, II, III, aVR, aVL, aVF, CR1-CR7, V1-V7, and the right oblique lead (RO) were recorded in all cases at rest as well as immediately, 4 , and 10 minutes after the end of graded exercise. On the bicycle the chest leads were recorded during each load (with the indifferent electrode attached to the forehead of the patient).

Received March 17, 1966.
This procedure was performed in every exercise test in the laboratory during nearly five months. During this trial about 400 subjects were examined. From all these tests two homogeneous groups were chosen for closer analysis.

In the first group were included all normal subjects who had volunteered to act as experimental subjects in hæmodynamic studies. They considered themselves to be healthy and had no symptoms of cardiac or pulmonary disease. The physical examination revealed no abnormal findings. The conventionally recorded electrocardiogram was normal at rest and in exercise. The age distribution is seen in Table $I$. The group consisted of 17 men and 13 women.

\section{TABLE I}

AGE DISTRIBUTION OF THE HEALTHY SUBJECTS (GROUP 1)

\begin{tabular}{l|c|c|c|c|c|c|c}
\hline & \multicolumn{5}{|c}{ Numbers in each age-group } \\
\cline { 2 - 5 } & $19-20$ & $21-25$ & $26-30$ & $31-35$ & $36-45$ & $46-55$ & $56-$ \\
\hline Wen & $\frac{5}{3}$ & 7 & 4 & 1 & 1 & 5 & 1 \\
\hline
\end{tabular}

In the second group were 18 patients, 14 men and 4 women. Their ages ranged between 48 and 67 years. These patients were referred for investigation because of clinically evident or suspected coronary heart disease. The routine cardiogram in all patients showed flat or sagging ST depression and/or T inversion (i.e. pathological ST-T changes) during the work test. This, together with the history, led to a diagnosis of coronary insufficiency.

\section{Results and Comments}

The comparisons between the routine electrocardiogram and the right oblique lead are shown in Table II.

In the healthy group 7 out of 17 men showed either biphasic or negative $T$ waves in the right oblique lead at rest. None of the women showed any changes. 
TABLE II

DETAILED DISTRIBUTION OF CHANGES IN RIGHT OBLIQUE TRANSTHORACIC ELECTROCARDIOGRAM IN RELATION TO CHANGES IN ROUTINE ELECTROCARDIOGRAM AT REST AND ON EXERCISE

\begin{tabular}{|c|c|c|c|c|c|c|c|c|}
\hline & & & \multicolumn{3}{|c|}{ Routine electrocardiogram } & \multicolumn{3}{|c|}{ Right oblique transthoracic electrocardiogram } \\
\hline & & & $\begin{array}{l}\text { Normal con- } \\
\text { figuration }\end{array}$ & $\begin{array}{l}\text { Possibly ab- } \\
\text { normal con- } \\
\text { figuration }\end{array}$ & $\begin{array}{c}\text { Pathological } \\
\text { ST-T changes }\end{array}$ & $\begin{array}{l}\text { Normal con- } \\
\text { figuration }\end{array}$ & $\begin{array}{l}\text { Biphasic } \\
\text { T wave }\end{array}$ & $\begin{array}{c}\text { Negative } \\
T \text { wave }\end{array}$ \\
\hline Controls & $\begin{array}{l}\text { Men } \\
\text { Women }\end{array}$ & $\begin{array}{l}\text { At rest } \\
\text { Exercise test } \\
\text { At rest } \\
\text { Exercise test }\end{array}$ & $\begin{array}{l}17 \\
17 \\
13 \\
13\end{array}$ & $\bar{z}$ & $\bar{z}$ & $\begin{array}{r}10 \\
2 \\
13 \\
6\end{array}$ & $\begin{array}{l}6 \\
2 \\
5\end{array}$ & $\frac{13}{2}$ \\
\hline Patients & $\begin{array}{l}\text { Men } \\
\text { Women }\end{array}$ & $\begin{array}{l}\text { At rest } \\
\text { Exercise test } \\
\text { At rest } \\
\text { Exercise test }\end{array}$ & $\left\{\begin{array}{l}\frac{4}{-} \\
=\end{array}\right.$ & $\begin{array}{l}- \\
z \\
-\end{array}$ & $\begin{array}{c}- \\
6^{\star} \\
14 \\
4 \\
4\end{array}$ & $\begin{array}{l}2 \\
2 \\
1 \\
-\end{array}$ & $\begin{array}{l}1 \\
1 \\
1 \\
2 \\
2 \\
1\end{array}$ & $\begin{array}{r}1 \\
1 \\
5 \\
11 \\
2 \\
3\end{array}$ \\
\hline
\end{tabular}

* Two cases included where the routine cardiogram showed pathological configuration of QRS but no certain ST-T changes at rest.

Evans' normal series consisted of $\mathbf{4 0}$ subjects, and in 5 of these (all 5 men) he found deviations from the cardiographic configuration considered normal in the right oblique lead. Of our 7 men with biphasic or negative T waves, 4 were $21,27,28$, and 38 years of age, respectively. With the age of these subjects in mind and without any history of cardiac disease, in combination with the normal exercise routine

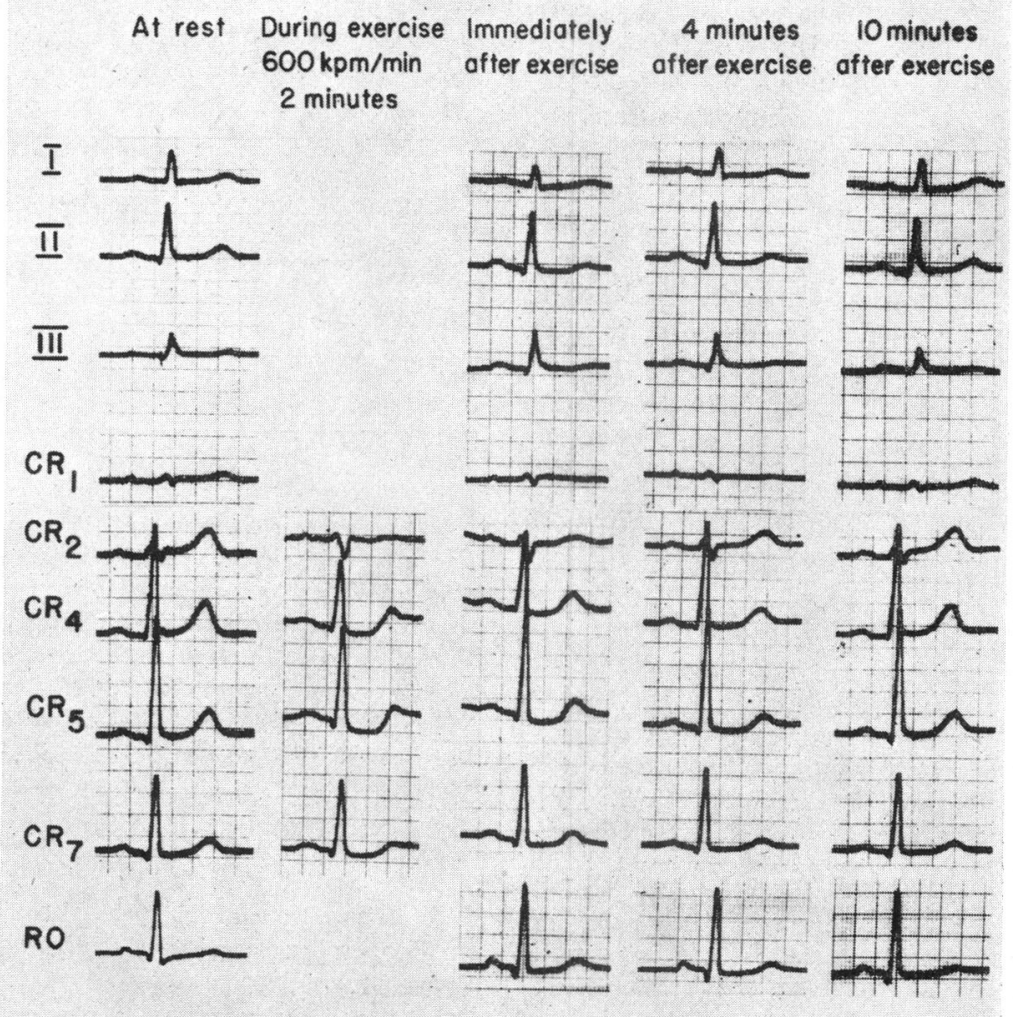

FIG. 1.-The routine electrocardiogram and the right oblique transthoracic electrocardiogram recorded at rest and on exercise in a man, age 57 years, with clinically evident coronary insufficiency since 1962. 


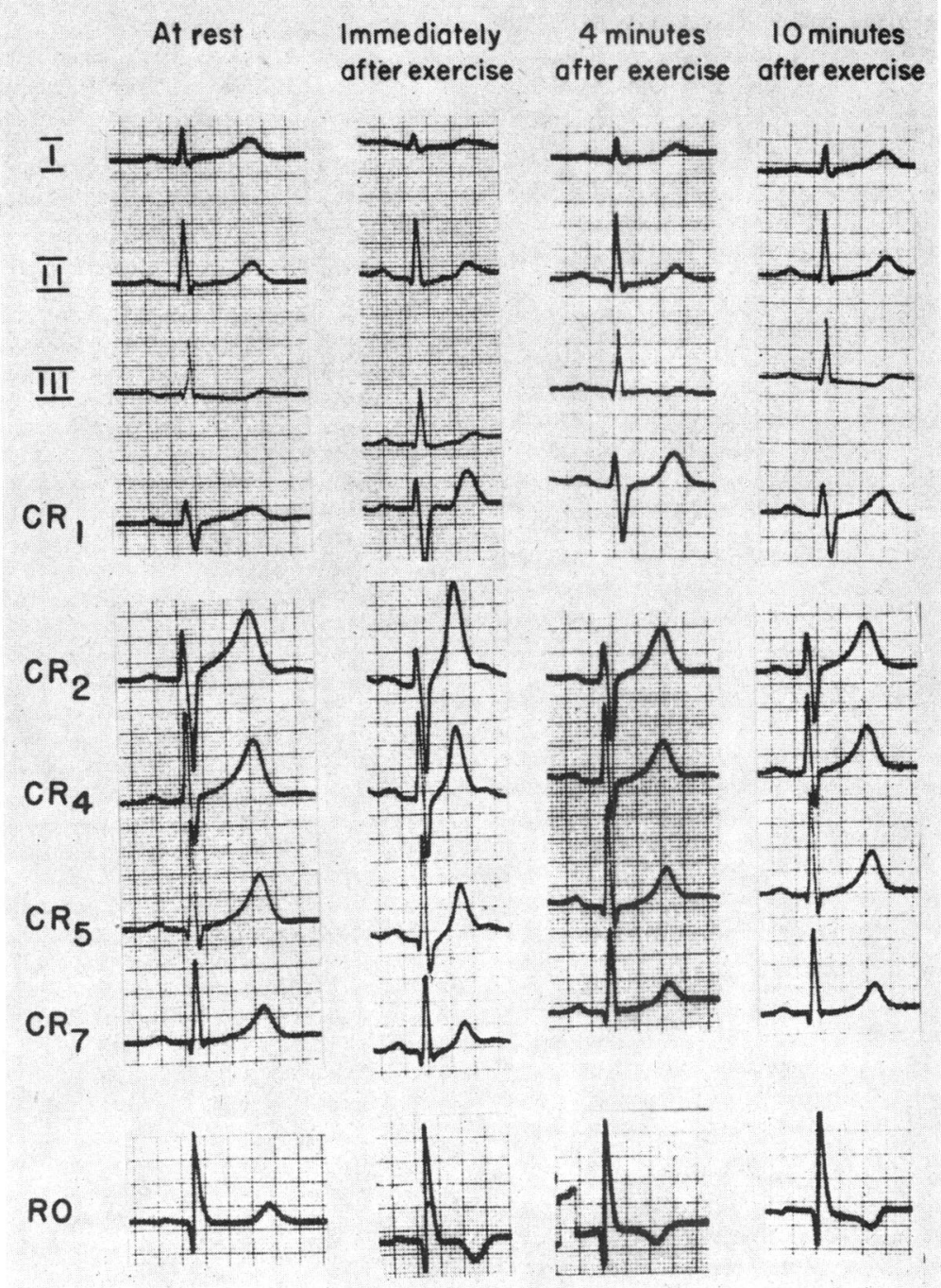

Fig. 2.-The routine electrocardiogram and the right oblique transthoracic electrocardiogram recorded at rest and on exercise in a healthy man, aged 27 years. The working capacity on the bicycle at steady state was estimated to be $1500 \mathrm{kpm} /$ minute.

electrocardiogram, we consider the diagnosis of coronary insufficiency unlikely.

With the exercise test only 2 men from the healthy group remained normal while 15 showed $T$ wave changes in the right oblique lead. Only 1 out of the 10 men between 21 and 33 years of age showed a normal configuration of this lead. The other 9 showed a negative $T$ wave. After work the $T$ waves of 7 of 13 women changed in the right oblique. The women were all between 19 and 28 years of age.

Among the patients, the routine electrocardiogram and the right oblique at rest showed no complete agreement between the leads. After exercise 13 out of 14 men and the 4 women showed ST-T changes in the latter.

The results from the complete investigation of all the exercise electrocardiograms that we recorded during nearly five months showed great variations in the configuration of the right oblique. This seemed to bear no sure relation to the configuration of the routine cardiogram before or after exercise.

In one patient we found a normal configuration of the right oblique lead together with obvious ST-T changes in the routine tracing (Fig. 1). This may 
seem remarkable. However, ST-T changes in the right oblique lead must depend on the different amplitudes recorded in CR1 and CR7. If the T wave in CR7 is smaller than the T wave in CR1, a $T$ inversion in the right oblique transthoracic cardiogram will occur. This does not exclude the possibility that the $T$ wave in CR7 is of normal height but that the $T$ wave in CR1 may still be higher. That is what seems to happen after work in most of the normal subjects (Fig. 2). This indicates a likely source of error when recording the right oblique at rest.

The experience from this limited series strongly suggests that a biphasic or negative $T$ wave in the right oblique lead cannot unreservedly be taken as evidence for cardiac infarction (Evans, 1965). It does seem unlikely that 22 out of the 30 relatively young subjects suffered from coronary heart disease.

Bipolar chest leads may be useful when the application is limited to adjacent areas of the heart (Carlsten, 1954). But it seems to us to be more valuable to record the unipolar chest lead tracing very carefully by increasing the number of leads or by moving the leads up and down the chest, thus covering larger areas of the heart than is usually done (Amsler, 1965).

\section{SUMMARY}

The right oblique lead (recorded between an electrode in the fourth intercostal space at the right border of the sternum, station 1, and one in the left posterior axillary line, station 7) has been used together with the routine leads at rest and on exercise test. Eighteen patients who showed pathological ST-T changes in the routine electrocardiogram during or after exercise, and 30 healthy adults, were thus examined.

In the limited series of patients with coronary heart disease this lead did not seem to increase the diagnostic accuracy.

The frequent abnormalities of the right oblique electrocardiogram in clinically normal subjects at rest and after exercise also diminish its usefulness for diagnostic purposes.

\section{REFERENCES}

Ackermann, R. (1924). Úber thorakale Ableitung des Elektrokardiogramms. Dtsch. Arch. klin. Med., 144, 61.

Amsler, H. A. (1965). Inapperzepte lokalisierte Myokardschäden. Helv. med. Acta, 32, 179.

Bengtsson, G. (1947). Om värdet av den parasternala avledningen (IIV sin.) vid kombinerade bröstavledningar. Nord. Med., 36, 2462.

Carlsten, A. (1954). On the significance of the bipolar chest lead in ECG between apex cordis and the left posterior axillary line. Scand. F. clin. Lab. Invest., 6, 110.

Drury, A. N., and Iliescu, C. C. (1921). The electrocardiograms of clinical fibrillation. Heart, 8, 171.

Einthoven, W., and de Lint, K. (1900). Úber das normale menschliche Elektrokardiogramm und über die capillarelektrometrische Untersuchung einiger Herzkranken. Pflügers Arch. ges. Physiol., 80, 139.

Evans, W. (1965). The right oblique transthoracic electrocardiogram. Brit. Heart f., 27, 252.

- , and Hunter, A. (1943). Chest lead CR7 in cardiac infarction. Brit. Heart $\mathcal{F}$., 5, 73.

Grewin, K. E. (1948). Some supplementary leads in clinical electrocardiography. Acta med. scand., 130, Suppl. 209.

Holmgren, A., and Mattsson, K. H. (1954). A new ergometer with constant work load at varying pedalling rate. Scand. F. clin. Lab. Invest., 6, 137.

Koenigsfeld, H., and Stroebe, F. (1923). UUber Elektrokardiogramm von Herzkranken bei Ableitungen mit Nadelelektroden. Z. klin. Med., 97, 182.

Lewis, T. (1910). Auricular fibrillation and its relationship to clinical irregularity of the heart. Heart, 1, 306.

Nehb, W. (1938). Zur Standardisierung der Brustwandableitungen des Elektrokardiogramms. Klin. Wschr., 17, 1807.

Nylin, G., and Sällström, T. (1938). Three synchronized leads between fixed points on the heart projection on the chest wall. Acta med. scand., 96, 1.

Sjöstrand, T. (1947). Changes in the respiratory organs of workmen at an ore smelting works. Acta med. scand., 128, Suppl. 196, 687.

- (1960). Functional capacity and exercise tolerance in patients with impaired cardiovascular function. In Clinical Cardiopulmonary Physiology, 2nd edn., ed. B. L. Gordon, p. 201. Grune \& Stratton, New York. (American College of Chest Physicians.)

Wahlund, H. (1948). Determination of the physical working capacity. Acta med. scand., 132, Suppl. 215.

Weinstein, J. (1934). Multi-plane chest electrocardiography. Ann. intern. Med., 7, 1503.

Whitten, M. B. (1937). Midaxillary leads of the electrocardiogram in myocardial infarction. Amer. Heart f., $13,701$.

Wolferth, C. C., and Wood, F. C. (1932). The electrocardiographic diagnosis of coronary occlusion by the use of chest leads. Amer. F. med. Sci., 183, 30. 